\title{
The Strategy of Pancasila and Civic Education Teachers in Building Student Character in the Covid-19 Pandemic
}

\author{
Tri Utami ${ }^{1 *}$, Suharno ${ }^{2}$, \\ ${ }^{1}$ Pancasila and Civic Education, Graduate Program Universitas Negeri Yogyakarta, Yogyakarta, Indonesia \\ ${ }^{2}$ Lecture, Universitas Negeri Yogyakarta, Yogyakarta, Indonesia \\ *Corresponding author.Email: tri327pasca.2019@student.uny.ac.id
}

\begin{abstract}
Character building of students in the Covid-19 Pandemic is very important. It is because all life systems change with all the existing rules to overcome the rapid growth of Covid-19. One of them is in the educational setting, where learning is carried out online, and besides, and the character of students in Indonesia decreases as indicated by the number of students who are caught in the act in public places during class hours. Therefore, to build student character, a proper strategy is needed by the civic education teacher. This study aims to describe the strategies used by the teacher in building the character of students in schools during the Covid-19 Pandemic. The approach used in this study is qualitative with a descriptive research type. The data sources used were primary data sources which were the Civic Education teachers, and secondary data sources were books and journal articles which were relevant to this research. The data collection was done by using interviews, and then the data were analyzed by using data reduction, data presentation, and conclusions. The results of this study indicate that there are several strategies used by Pancasila and Citizenship Education teachers at Senior High School State 01 Kandawangan in shaping the character of students during the Covid-19 pandemic, including 1) By communicating with students through social media such as WhatsApp groups. 2) With direct admonition/advice. 3) Prepare interesting teaching materials. 4) Habit. 5) Cooperate with students' parents. The teachers' strategy was to provide habituation for students to analyze and discuss during online learning.
\end{abstract}

\section{Keywords: Civic Education Teachers'Strategy, Character, Covid-19}

\section{INTRODUCTION}

The success of a nation in achieving its objectives is not only determined by the abundance of natural resources but is largely determined by the quality of its human resources. Education is a means of shaping the character of the nation which has noble goals. As the educational function stated in Law Number 20 of 2003 concerning the National Education System which explains that:

National education has the function of developing abilities and shaping dignified national character and civilization to educate the nation's life, aiming to develop the potential of students to become human beings who believe and fear God Almighty, have a noble character, healthy, knowledgeable, competent, creative, independent, and become a democratic and responsible citizen [1].
Based on the objectives of education in national education, it functions to develop and shape the character of students. Thus education has an important role in the process of forming the character of students. Education is expected to change the mindset and behavior from bad things to good things for students [2].

The character can be interpreted as a special sign or characteristic, thus giving birth to a view that a character is a pattern of individual behavior, a person's moral condition. The character can be interpreted as basic values that build a person's personality, are shaped both due to the influence of heredity and environmental influences, which differentiate him from other people, and are manifested by his attitudes and behavior in everyday life [3]. Good character includes good knowledge [4]. This means that character is an attitude that shows the goodness done by each individual, including thinking well, feeling good, and having good behavior so that they can become wise human beings with noble character. This means that character is an attitude that shows the goodness done by each individual, including thinking well, feeling good, and having good behavior so that they can become wise human beings with noble character. Character is also said to be an action to achieve something from a person's attitude, including intellectual, social, and emotional aspects to 
provide good character values in him, so that the character is related to these aspects [5]. The formation of good character in students is a priority that must be implemented to make them wise human beings in the future.

Today, it is easy to find the tendency of behavior that is contrary to democratic values and principles by schoolage children. Various behavioral phenomena that are contrary to the spirit of democracy, such as student brawls, committing violations, and legal crimes, violating the prevailing norms in society (law, religion, morality, and manners), lack of nationalism and patriotism, disrespect. And respecting the rights of others, refusing to exercise their rights and obligations, not recognizing and respecting multiculturalism, and other behaviors have not the least resulted in fatal events. Moral decadence has been rampant in the world of education so that it has become a blurry portrait in the world of education. This can be seen from the rampant circulation of pornographic videos played by students, rampant fights between students, cheating on national exams, the number of drug cases that ensnare students, the number of motorbike robbers played by students, school separation in bikinis. Furthermore, Ningrum [7] stated that Indonesian adolescents are very far from religious teachings and deviant behavior such as promiscuity and free sex which are considered common among today's teenagers. This fact shows that behavior that is contrary to the spirit of democracy for school-age children is one of the most complex and comprehensive social problems that can hinder the pace of development because these problems can disrupt order, peace, and security both physically, spiritually, and socially in life together., directly or indirectly.

However, the current moral crisis that is occurring among Indonesia's young generation does not close hopes of developing good-moral Indonesian human resources [8]. With character education, it can help foster a sense of sociality in students in the surrounding environment. Character education is a system of inculcating character values which includes components of knowledge, awareness, or willingness, and actions to carry out these values, both towards God Almighty, self, neighbor, environment, and nationality [9]. In line with this, Daryanto \& Darmiatun [10] explained that character education is an effort made by school personnel, even carried out with parents and community members, to help adolescents become or have a caring, opinionated, and responsible nature. Character education provides knowledge to students that the character they have does not only bring students to become good personalities but can improve the quality of students. Therefore, it is very important to provide character education to students in providing provisions to become good personalities in the future.

However, currently, the character building of students is a big challenge for teachers. This is because Indonesia and even the world are being tested by the presence of Covid-19. Covid-19 is a new name given by the World Health Organization (WHO) for patients with the 2019 corona novel virus infection which was first reported from the city of Wuhan [11]. The Covid-19 pandemic has had a huge impact in various fields such as social, economic, tourism, and education. The crisis came suddenly, governments anywhere in the world including Indonesia had to make a bitter decision to close schools to reduce contact with people massively and to save lives or still have to open schools to survive workers in maintaining economic sustainability [12]. A circular issued by the government on 18 March 2020 all indoor and outdoor activities in all sectors have been temporarily postponed to reduce the spread of corona, especially in the education sector. On March 24, 2020, the Minister of Education and Culture of the Republic of Indonesia issued Circular Number 4 of 2020 concerning the Implementation of Education Policies in an Emergency for the Spread of Coved, which explained that the learning process was carried out at home through online / distance learning to provide a meaningful learning experience students. Online/distance learning requires teachers and students not to meet face to face, where teachers cannot directly monitor the character development of students and teachers must make the right strategy so that the character formation of students can run properly. Based on this background, the researcher was interested in researching how the strategies of Pancasila and Citizenship Education Teachers at the Senior High School State 01 Kandawangan in shaping the character of students in the Covid-19 era.

\section{METHOD}

The research approach used in this research is a qualitative approach with descriptive research type. Creswell [13] provides a more specific definition of qualitative research as part of educational research that Qualitative research is a type of educational research in which the researcher relies on the views of participants; asks broad, general questions; collect data consists largely of words (or text) from participants; describes and these words for themes; and conducts the inquiry in a subjective, biased manner. The idea can be interpreted that qualitative research is one of educational research where the researcher bases his research on the views of the participants, the researcher asks broadly, the questions are more general, the researcher collects data that is mostly in the form of words or text from the participants, then the researcher describes and analyze these words to suit the research theme, and carry out investigations in a more subjective way.

The type of research used in this research is descriptive. Descriptive research according to Sukmadinata [14] is aimed at describing and describing existing phenomena, both natural and human engineering, which pay more attention to human characteristics, quality, and linkages between activities. Besides, descriptive research does not provide treatment, manipulation, or alteration of the variables under study, but rather describes a condition as it is.

Data collection techniques used in this study were interviews. Mulyadi, Basuki \& Prabowo [15] revealed that 
the interview is a face-to-face question and answer activity between the interviewer and the interviewee about the problem being researched, where the interviewer intends to get the perceptions, attitudes, and mindset of the interviewee that is relevant to the problem at hand. researched. Researchers conducted in-depth interviews via zoom or online with Pancasila and Citizenship Education teachers at the Senior High School State 01 Kandawangan as a research resource to obtain information related to their strategies in character building in the Covid-19 era. After the data is collected, the researcher analyzes the data obtained so that the data is valid and verified. The qualitative research approach uses inductive analysis which is based on the facts found in the research location [16]. In this study, using an interactive model of qualitative data analysis according to Miles, Matthew, \& Huberman [17] which consists of three activities occurring simultaneously, namely 1) data reduction, 2) data presentation, 3) concluding / verification.

\section{RESULT AND DISCUSSION}

\subsection{The Strategy of Pancasila and Civic Education Teachers in Building Student Character in the Covid-19 Pandemic}

\subsubsection{Pancasila and Citizenship Education Teacher Strategies in Forming Student Character in the Covid-19 Era}

Citizenship education is one of the fields of study that has a national mission to educate the life of the Indonesian nation through value-based education [18]. As in the Regulation of the Minister of National Education Number 22 of 2016 which states that citizenship education subjects are subjects that focus on the formation of citizens who understand and can exercise their rights and obligations to become smart, skilled, and character Indonesian citizens mandated by Pancasila and the 1945 Constitution [19]. Besides, civic education is an educational concept that functions to shape students as citizens who have a character [20]. Pancasila and Citizenship Education Teachers have the responsibility to explore, foster, and shape the personalities of their students so that they understand, live, and practice the values of Pancasila. Besides, Pancasila and Citizenship Education teachers must have the right strategy in shaping the character of students in the current Covid-19 pandemic era.

Based on the research conducted, the strategies used by the Pancasila and Citizenship Education Teachers at the Senior High School State 01 Kandawangan in shaping the character of students in the Covid-19 era are as follows. (1) By communicating with students via social media such as WhatsApp groups. By using social media, the process of communicating with students is very easy and doesn't take a long time. So that teachers easily convey information and reinforce character education to students. This is in line with what Koni [21] expressed that social networks are very influential on character education of students because more students focus more on social networks. (2) With direct reprimand/advice. The reprimand given by the Pancasila and citizenship education Teacher at the Senior High School State 01 Kandawangan in the Covid-19 era was when students did not focus or were late in online classes. Reprimands are given along with advice to students so that it is hoped that these students will not repeat it and can change their attitude for the better. (3) Prepare interesting teaching materials. The strategy carried out by Pancasila and Citizenship Education Teacher at the Senior High School State 01 Kandawangan in shaping the character of students in the Covid-19 pandemic era is to prepare interesting teaching materials, because online learning can provide saturation to students, therefore teaching materials are displayed must be able to make students motivated in the learning process so that learning objectives can be achieved properly. (4) Habit. The habituation applied Pancasila and Citizenship Education teacher of Senior High School State 01 Kandawangan in shaping the character of students in the Covid-19 era is by giving assignments to students in the form of "Blue Notes". Blue notes are notes of what good things students do which will be reported every week to the teacher. This activity is intended so that students can apply 18 characters according to the Ministry of National Education [22] which include religious, honest, tolerance, discipline, hard work, creative, independent, democratic, curiosity, tolerance, discipline, hard work, creative, independent, democratic, curiosity, national spirit, love for the country, respect for achievement, friendly/communicative, love peace, love to read, care about the environment, care about social, responsibility. (5) Cooperate with the parents of students. Parents have an important role in the process of forming the character of students. In the era of the Covid19 pandemic, students spend more time studying at home. Therefore, teachers and parents must work together in shaping and providing character education to students. As stated by Syahroni [23] the role of parents and schools requires synergy in developing student character. The academic ability that covers all aspects of character, even body, and soul, is not solely the responsibility of the school (teacher), and this is the key to the success of students to become superior human resources [24].

\subsubsection{Inhibiting Factors for Teachers of Pancasila and Citizenship Education in Forming Student Character in the Covid-19 Era}

Based on research conducted at the Senior High School State 01 Kandawangan, there are several factors inhibiting teachers in shaping the character of students in 
the Covid-19 era, which are as follows. (1) Lack of openness of students to the problems or obstacles faced. This causes many students who are still late in collecting assignments, many are still late in attending the learning process. (2) When reprimanded or given advice when something is wrong, students sometimes often argue and repeat the same thing at the next meeting. (3) Lack of awareness of students to behave following good characters. (4) Lack of understanding of the use of technology. This was felt by teachers of Pancasila and Citizenship Education at the Senior High School State 01 Kandawangan so that it was difficult to show creativity in the process of character building for students. (5) Another inhibiting factor is the lack of awareness and high encouragement from parents to students. This is due to a lack of awareness of the responsibilities of parents in guiding students in the learning process in the era of the Covid-19 pandemic.

\subsubsection{Pancasila and Citizenship Education Teachers' Efforts to Overcome Barriers to Character Building Students in the Covid-19 Era}

Based on research conducted at the Senior High School State 01 Kandawangan, there are several efforts made by Pancasila and citizenship education teachers in the Covid-19 era in overcoming obstacles in shaping the character of students, as follows. (1) Pancasila and Citizenship Education Teachers at Senior High School State 01 Kandawangan collaborate with Counselling Guidance teachers in admonishing students who repeatedly make the same mistakes. (2) Pancasila and Citizenship Education Teachers at Senior High School State 01 Kandawangan always try to learn ways or media that are easy to use via YouTube to find out the development of student character. (3) Always try to build good communication with parents of students. By coordinating well with the parents of students, it is hoped that it can help teachers overcome obstacles in shaping the character of students. Besides, it can also help teachers get information about the development of students in the Covid-19 pandemic era.

The solution proposed by the author in the efforts of Citizenship Education teachers in overcoming the character building of students is by combining the Citizenship Education learning process that is carried out online with everyday life. The point is that in the learning process of Pancasila and Citizenship Education, students are invited to think, analyze, and tell what activities they can do during a pandemic that can shape their character. Therefore, in the process of making a Learning Implementation Plan, the teacher must include character values into the learning material. This is because through civic education each needs to develop knowledge, attitudes, and skills, as an effort to prepare himself for the wider context of life in society [25]. Besides, the civic education provided is to prepare them to become good citizens and to develop civic competences in general [25].
Pancasila and Citizenship Education has a role in developing three competencies, namely civic skills, civic knowledge, and civic disposition.

\subsection{Our Contribution}

This paper presents how the strategies of the Pancasila and Citizenship Education teachers in shaping the character of students in the Covid-19 pandemic, this paper also examines what supporting factors can help the process of forming student character and what factors can hinder the process of forming student character in the Covid-19 pandemic.

\subsection{Paper Structure}

The rest of this paper is organized as follows: Part 1 introduces the background for the writing of this paper, where the author wants to see the importance of the character-building strategy of students during the Covid19 pandemic. Section 2 presents the methods used in the process of compiling results and discussions. Then in Part 3 the results and discussion discuss how the strategies of Pancasila and Citizenship Education teachers in shaping the character of students during the COVID-19 pandemic. Section 4 concludes the paper and provides direction for future research

\section{CONCLUSION}

The formation of the character of students can be realized by the educational process. As National Education functions to develop abilities and shape dignified national character and civilization in the framework of educating the nation's life, aims to develop the potential of students to become human beings who believe and fear God Almighty, have noble, healthy, knowledgeable, competent, creative character, independent, and become a democratic and responsible citizen. The Covid-19 pandemic that hit Indonesia is a challenge for Pancasila and Citizenship Education teachers in determining the right strategy for character building students. Based on the results of research that has been carried out in Senior High School State 01 Kandawangan, the strategies of the Pancasila and Citizenship Education teachers. 1) By communicating with students via social media such as WhatsApp groups. 2) With direct admonition/advice. 3) Prepare interesting teaching materials. 4) Habit. 5) Cooperate with students' parents. The obstacles faced by teachers of Pancasila and Citizenship Education at Senior High School State 01 Kandawangan include: 1) the lack of openness of students to the problems or obstacles they face. 2) When reprimanded or given advice when something is wrong, students sometimes often argue and repeat the same thing at the next meeting. 3) Lack of awareness of students to 
behave following good characters. 4) Lack of understanding of the use of technology. 5) Another inhibiting factor is the lack of awareness and high encouragement from parents to students. The efforts made by Pancasila and citizenship education teachers in the Covid-19 era in overcoming obstacles in shaping the character of students are as follows. 1) The teacher collaborates with the Counselling Guidance teacher. 2) The teacher tries to learn ways or media that are easy to use via YouTube. 3) Always try to build good communication with parents of students.

\section{ACKNOWLEDGMENT}

This article is supported by Nanik Fitriani, S.Pd. because she has provided suggestions so that the authoress can complete this article. Then, the authors also conveys to Ah. Marwan, S.Pd as proofread of this article and the committee The International Conference on Character Education (ICCE) the University of Muhammadiyah Semarang as a reviewer for this article.

\section{REFERENCES}

[1] Undang-Undang Nomor 20 Tahun 2003 Tentang Sistem Pendidikan Indonesia.

[2] Sinta, I. (2015). Strategi guru PPKn dalam membentuk karakter peserta didik di SMP Negeri 1 Mojokerto. Kajian Moral dan Kewargaraan. 02(03). 560-574.

[3] Samani, M. \& Hariyanti. (2013). Konsep dan model pendidikan karakter. Bandung: PT Remaja Rosdakarya.

[4] Lickona, T. (1992). Education for character how our school can teach respect and responsibility. New York-Toronto-London_Sidney-Auckland: Bantam Books.

[5] Agboola, A, \& Tsai, K. C. (2012). Bring character education into classroom. European Journal of Education research. 1(2), 163-170. Doi: 10.12973/eujer.1.2.163.

[6] Maunah, B. (2015). Implementasi pendidikan karakter dalam pembentukan kepribadian holistik siswa. Jurnal Pendidikan Karakter. V(1). 90-101. Doi: https://doi.org/10.21831/jpk.v0i1.8615.

[7] Ningrum, D. (2015). Kemerosotan Moral di Kalangan Remaja: Sebuah Penelitian Mengenai Parenting Styles dan Pengajaran Adab. UNISIA. Vol XXXVII. N0 82.
[8] Haryani, S. \& Murdiono, M. (2019). Strategi guru PPKn dalam pembentukan karakter sopan santun di sekolah menengah pertama kejuruan. Jurnal Pendidikan Kewarganegaraan dan Hukum. 8(1). 67-76.

[9] Omeri, N. (2015). Pentingnya pendidikan karakter dalam dunia pendidikan. Manajer Pendidikan. 9(3). 464-468.

[10] Daryanto \& Darmiatu, S. (2013). Implimentasi pendidikan karakter di sekolah. Yogyakarta: Gave Media.

[11] Handayani, D., Hadi, R. D., Isabaniah, F., Burhan, E., \& Agustin, H. (2020). Penyakit virus corona 2019. Jurnal Respirologi Indonesia. 40.(2). Doi: https://doi.org/10.36497/jri.v40i2.101.

[12] Aji, S. H. R. (2020). Dampak covid-19 pada pendidikan Indonesia: sekolah, keterampilan, dan proses pembelajaran. Jurnal Sosial \& BudayaSyar-i. 7(5). 395-402. Doi: https://doi.org/10.15408/sjsbs.v7i5.15314.

[13] Creswell. J W. (2008). Educational Research: Planning, Conducting, and Evaluating Quantitative and Qualitative Research.USA: Person Education International.

[14] Sukmadinata, S. N. (2011). Metode penelitian pendidikan. Universitas Pendidikan Indonesia: PT Remaja Rosdakarya.

[15] Mulyadi, S., Basuki, H., \& Prabowo, H. (2019). Metode penelitian kualitatif dan mixed method: prespektif yang terbaru untuk ilmu-ilmu sosial, kemanusian, dan budaya. Depok: Rajawali Pres

[16] Given, M. L. (2008). The sage enclylopedia of qualitative research method. Singapore. Sage Publisher.

[17] Miles, M. B. hubeman, A. M., \& Saldana, J. (2014). Qualitative data analysis, a methods sourcebool. Edition 3. USA: Sage Publications. Terjemahan Tjetjep Rohindi Rohindi, UI.

[18] Sunarso, (2013). Pendidikan Kewarganegaraan: PKn Untuk Perguruan Tinggi. UNY: Press.

[19] Peratuturam Menteri Pendidikan dan Kebudayaan. (2016). Nomor 22 Tahun 2016 Tentang Mata Pelajaran Pendidikan Kewarganegaraan. 
[20] Suardi, Herdiansyah, Ramlan, H., \& Mutiari, A. I. (2019). Implementasi pendidikan karakter melalui mata pelajaran pendidikan kewarganegaraan di sma jaya negara makasar. Jurnal Etika Demokrasi Pancasila dan Kewarganegaraan. 4(1). 22-29. Doi: https://doi.org/10.26618/jed.v4il.1983.

[21] Koni, M. S. (2016). Pengaruh jejaring sosial terhadap pendidikan karakter peserta didik. Jurnal Manajemen Pendidikan Islam. 4(2). 37-43.

[22] Kementrian Pendidikan Nasional. (2011). Pedoman pendidikan karakter. Jakarta: Pusat Kurikulum Perbukuan.

[23] Syahroni, S. (2017). Peranan orang tua dan sekolah dalam pengembangan karakter anak didik. Jurnal Intelektualita: Keislaman, Sosial, dan Sains. 6(1). 1328. Doi: https://doi.org/10.19109/intelektualita.v6i1.1298.

[24] Wardhani, Y. Z. T. \& Krisnani, H. (2020). Optimalisasi peran pengawasan orang tua dalam pelaksanaan sekolah online di masa pandemic covid-19. Prosiding Penelitian \& Pengabdian Kepada Masyarakat. $\quad 7(1) . \quad$ 48-59. Doi: https://doi.org/10.24198/jppm.v7i1.28256.

[25] Alfiansyah, H. R., \& Wangid, M.N. (2018). Muatan pendidikan kewarganegaraan sebagai upaya membelajarkan civic knowladge, civic skill, dan civic disposition di sekolah dasar. Jurnal Pembangunan Pendidian. 6(2). 185-194. Doi: https://doi.org/10.21831/jppfa.v6i2.237664.

[26] Merry, S. M. \& Schinkel, A. (2016). Voting rights for older children and civic education. Public Affairs Quarterly. 30(3). 197-213. http://www.jstore.com/stable/44732769 